\title{
Perancangan Sistem Informasi Data Spasial Bangunan yang Memiliki KRK-IMB di Dinas Tata Ruang Tata Bangunan dan Perumahan Kota XYZ
}

\author{
Rita Komalasari,S.Si.,M.Kom ${ }^{1}$, Asye Rachmawaty, ST.,M.M \\ Dosen Prodi Manajemen Informatika \\ Politeknik LP3I Bandung \\ Email: ritakomalasari123456@gmail.com, asyerachmawaty@gmail.com
}

\begin{abstract}
Abstrak: E-government adalah kemampuan dari pemerintah untuk melakukan pelayanan pada publik/masyarakat menggunakan aplikasi teknologi yang tersedia dan beralih dari sistem manual yang ada saat ini sehingga proses dapat berlangsung secara tepat dan cepat dan masyarakat dapat mengakses secara langsung ke aplikasi sehingga segi transparansi dapat tetap terjaga. Dinas Tata Ruang Tata Bangunan dan Perumahan Kota XYZ membuat suatu aplikasi untuk dapat mengakses informasi mengenai bangunan yang memiliki KRKIMB berbasis spasial guna menanggapi kebutuhan masyarakat akan informasi penataan ruang.
\end{abstract}

Kata Kunci: E-goverment, Sistem Informasi, Data Spasial Bangunan

\section{Pendahuluan}

\subsection{Latar Belakang Masalah}

E-Government artinya menyelenggarakan roda pemerintahan dengan bantuan (memanfaatkan) teknologi informasi, yakni melakukan transformasi sistem proses kerja dari secara manual ke sistem yang berbasis elektronik. Tentu saja tidak semua proses kerja dapat ditransformsi ke dalam sistem elektronik. Ada beberapa yang masih harus mengunakan sistem manual, tetapi ada sebagian besar lainnya yang dapat dikerjakan dengan lebih cepat, efektif dan efisien melalui bantuan sistem elektronik.

Dengan demikian, Penyelenggaraan Sistem Elektronik di lingkungan Instansi Pemerintah Pusat dan Daerah, selanjutnya disebut e-government adalah pemanfaatan Teknologi Informasi untuk meningkatkan efisiensi, efektivitas, transparansi,dan akuntabilitas penyelenggaraan pemerintahan, dengan tujuan:

a. Meningkatkan mutu layanan publik melalui pemanfaatan teknologi IT dalam proses penyelenggaraan pemerintahan

b. Terbentuknya kepemerintahan yang bersih, transparan, dan mampu menjawab tuntutan perubahan secara efektif

c. Perbaikan organisasi, sistem manajemen, dan proses kerja kepemerintahan

Salah satu urusan penyelenggaraan pemerintahan adalah urusan penataan ruang. Urusan ini berpijak pada UU No. 26 Tahun 2007 tentang Penataan Ruang, yang dijabarkan dalam PP No. 15 Tahun 2010 tentang Penyelenggaraan Penataan Ruang, bahwa :

a. Penyelenggaraan meliputi Pengaturan, Pembinaan, Pelaksanaan, Pengawasan. 
b. Pelaksanaan Penataan Ruang meliputi perencanaan tata ruang, pemanfaatan ruang, dan pengendalian pemanfaatan ruang

c. Pengendalian pemanfaatan ruang meliputi Peraturan zonasi, perizinan, insentif dan disinsentif, dan sanksi.

Dinas Tata Ruang Tata Bangunan dan Perumahan (DTRTBP) Kota XYZ juga tidak terlepas dari konsekuensi tersebut dan mulai berupaya membuat suatu aplikasi untuk menampilkan informasi mengenai bangunan yang memiliki KRK-IMB. Kegiatan Pembuatan Informasi Data Spasial Bangunan Yang Memiliki KRK-IMB bertujuan menghasilkan suatu aplikasi sistem informasi mengenai bangunan yang telah memiliki KRK-IMB berbasis spasial. yaitu informasi spasial dan nonspasial bangunan. Informasi spasial tersebut berupa koordinat posisi bangunan yang disajikan dalam bentuk peta atau citra, sementara informasi nonspasialnya berupa keterangan mengenai IMB bangunan tersebut seperti nomor SK IMB, nama pemilik bangunan, lokasi bangunan, fungsi bangunan, luas bangunan dan informasi lainnya.

Untuk melaksanakan amanat urusan penataan ruang tersebut, saat ini diperlukan sistem kerja yang sudah menerapkan platform E-Government, mengingat perkembangan teknologi informasi yang pesat serta kecepatan kebutuhan informasi khususnya informasi penataan ruang yang semakin tinggi dari masyarakat, menuntut pemerintah harus cepat dalam melayani masyarakat dan pengambilan keputusan. Kondisi tersebut dibutuhkan mengingat informasi penataan ruang disisi lain pemicu pengembangan suatu wilayah dan menimbulkan dampak tertentu bagi lingkungan baik fisik maupun sosial.

\section{Tinjauan Pustaka}

Sesuai dengan Peraturan Pemerintah Nomor 15 Tahun 2010 tentang Penyelenggaraan Penataan Ruang, salah satu upaya untuk meningkatkan kinerja penataan ruang yang diselenggarakan oleh pemerintah daerah adalah pengembangan sistem informasi dan komunikasi penataan ruang melalui penyediaan basis data dan informasi bidang penataan ruang dengan sistem elektronik.

Peraturan perundang-undangan yang terkait dengan Pembuatan Informasi Data Spasial Bangunan yang memiliki KRK-IMB adalah sebagai berikut:

a. Undang-Undang Nomor 26 Tahun 2007 tentang Penataan Ruang.

b. Peraturan Pemerintah Nomor 15 Tahun 2010 tentang Penyelenggaraan Penataan Ruang.

c. Peraturan Menteri Dalam Negeri Nomor 8 Tahun 1998 tentang Perencanaan Penataan Ruang.

\subsection{Teori Analisis Dan Perancangan Sistem}

Analisis sistem (system analysis) dapat didefinisikan sebagai penguraian dari suatu proses informasi yang utuh ke dalam bagian-bagian komponennya dengan maksud untuk mengidentifikasikan dan mengevaluasi setiap permasalahan, kesempatan, hambatan yang terjadi dan kebutuhan yang diharapkan sehingga dapat diusulkan perbaikan. Tahap analisis 
ini dilakukan setelah tahap perencanaan sistem dan sebelum tahap desain analisis merupakan tahap yang kritis dan sangat penting, karena apabila terjadi dalam tahap ini akan menyebabkan juga kesalahan di tahap selanjutnya.

Di dalam tahap analisis sistem terdapat 4 tahap yang umum dilakukan pada saat menganalisis sistem, yaitu:

a. Survey, Tahap ini menjadi penting peranannya jika sistem yang dikembangkan akan digunakan sebagai pengganti sistem lama.

b. Analisis Sistem, Tahap ini meliputi pengumpulan data mengenai kebutuhan para user dan tujuan yang ingin dicapai jika system baru sudah berjalan.

c. System Requirement, Pada tahap ini ditentukan syarat-syarat yang harus dipenuhi agar sistem baru dapat berjalan umumnya ditentukan berdasarkan input yang dibutuhkan dan output yang dikehendaki.

d. Pelaporan Hasil Analisis, Laporan hasil analisis sebaiknya berisi spesifikasi-spesifikasi yang diinginkan oleh para user dan perancangan sistem secara global.

Untuk dapat melakukan pengembangan sistem secara berorientasi objek, maka dibutuhkan alat untuk memudahkan dalam analisis dan pengembangan sistem tersebut. Alat-alat tersebut umumnya berupa gambar, diagram atau grafik. Penggunaan gambar atau diagram ini lebih terarah dan lebih dimengerti, tetapi ada juga yang tak berupa grafik atau diagram.

Alat-alat yang berbentuk diagram diantaranya adalah :

a. Diagram Use Case

Diagram use case merupakan pemodelan untuk menggambarkan kelakuan (behavior) sistem secara keseluran yang akan dibuat. Diagram use case mendeskripsikan sebuah interaksi antara satu atau lebih aktor dengan sistem yang akan dibuat. Dengan pengertian yang cepat, diagram use case digunakan untuk mengetahui fungsi apa saja yang ada di dalam sebuah sistem dan siapa saja yang berhak menggunakan fungsi-fungsi tersebut.

b. Diagram Kelas

Diagram kelas atau class diagram menggambarkan struktur sistem dari segi pendefinisian kelas-kelas yang akan dibuat untuk membangun sistem.

c. Diagram Sequence

Diagram sekuen menggambarkan kelakuan / perilaku objek pada use case dengan mendeskripsikan waktu hidup objek dan message yang dikirimkan dan diterima antar objek. Oleh karena itu untuk menggambar diagram sekuen maka harus diketahui objekobjek yang terlibat dalam sebuah use case beserta metode-metode yang dimiliki kelas yang diinstansiasi menjadi objek itu.

d. Diagram Aktivitas

Diagram aktivitas atau activity diagram menggambarkan workflow (aliran kerja) atau aktivitas dari sebuah sistem atau proses bisnis. Yang perlu diperhatikan disini adalah bahwa diagram aktivitas menggambarkan aktivitas sistem bukan apa yang dilakukan aktor, jadi aktivitas yang dapat dilakukan oleh sistem.

e. Flowchart Program 
Flowchart Program merupakan diagram yang menjelaskan secara detil langkah-langkah dari proses program yang terdapat pada Flowchart Sistem. Simbol yang digunakan antara lain :

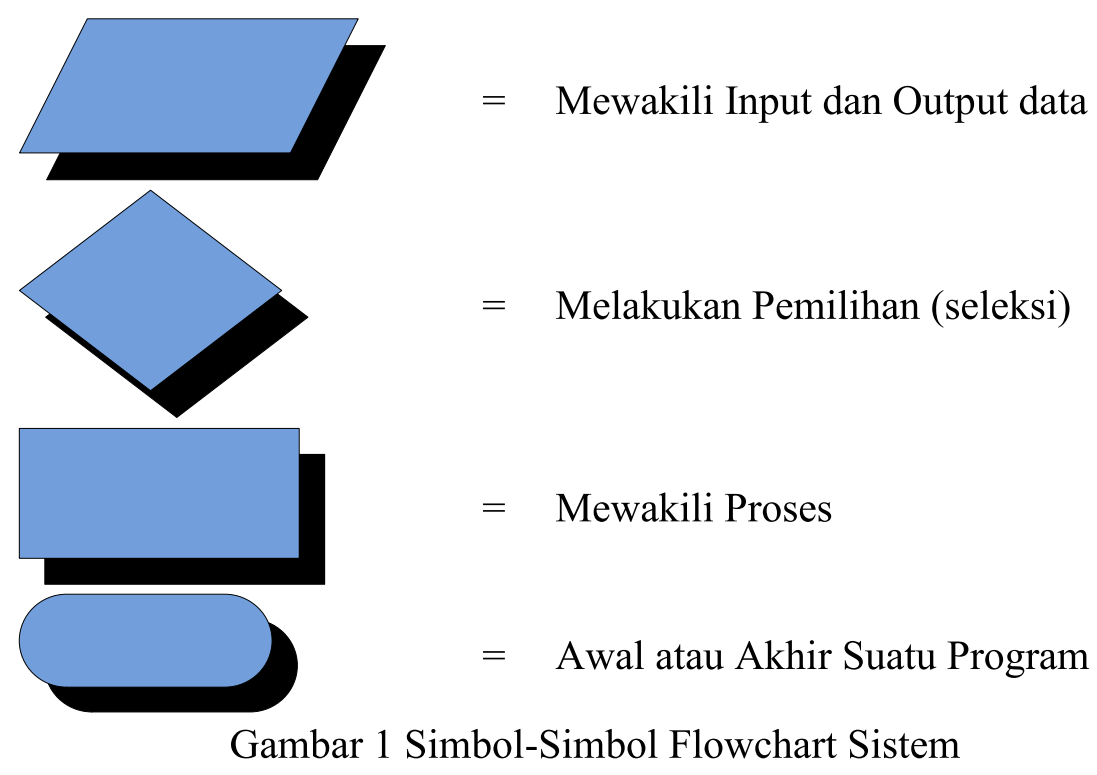

\subsection{Metode Pengembangan GIS}

Data geografi secara tradisional ditampilkan dalam bentuk peta (hardcopy). Analisis data geografipun biasanya dilakukan dengan mengoverlaykan peta secara manual. Hal ini mengakibatkan lambannya proses perencanaan suatu areal geografis menggunakan overlay manual data geografis tersebut. Pesatnya laju perkembangan teknologi komputer melalui pemetaan digital telah memangkas waktu analisis dan prerencanaan geografis secara efektif. Teknologi yang terakhir ini disebut sebagai Teknologi Sistem Informasi Geografis.

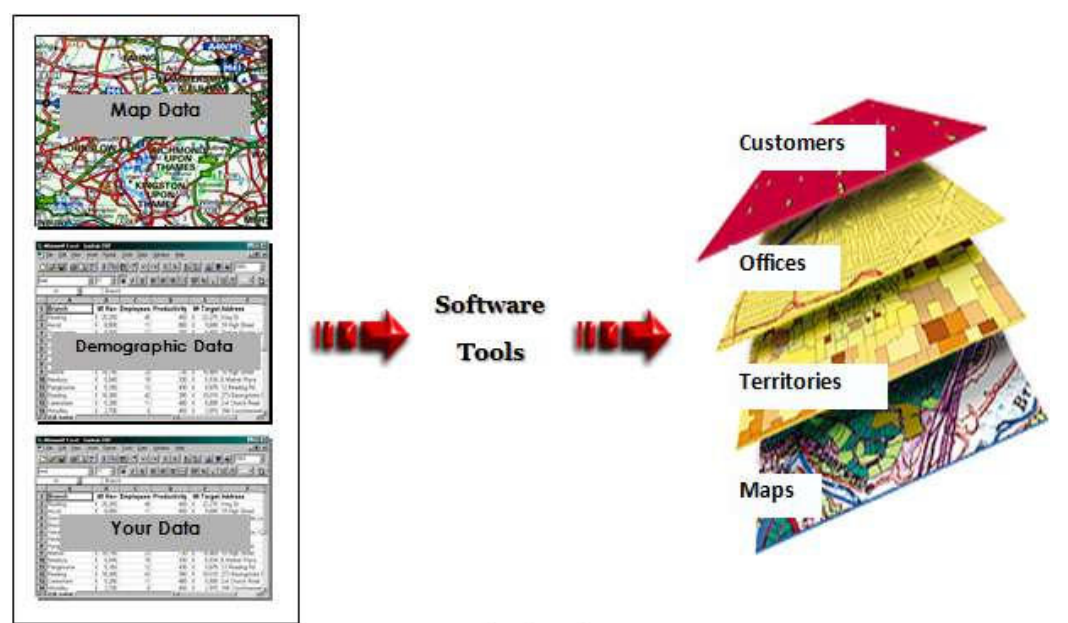

Gambar 2 Basis Pemetaan Digital Untuk GIS 
SIG merupakan sistem berbasis komputer yang digunakan untuk menyimpan dan memanipulasi informasi geografis. SIG dapat menyediakan informasi yang lebih baik untuk mendukung jenis pengambilan keputusan yang cukup kompleks. Seiring dengan pesatnya kemajuan hardware dan software SIG, model-model yang lebih kompleks pun dapat dikembangkan.

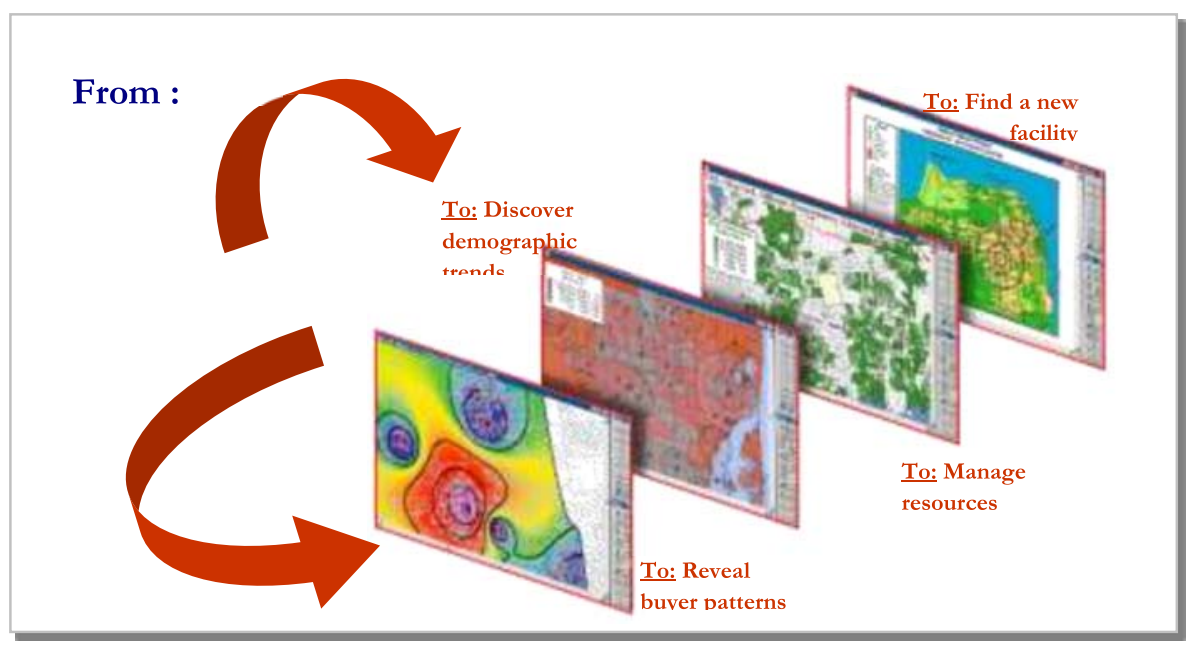

\section{Gambar 3 Konsep GIS}

Menurut jenisnya ada dua jenis data yang terlibat dalam sistem ini, yaitu:

a. Data Spasial / Peta

b. Data Atribut / Tekstual

Menurut kegunaannya, terdapat pula dua jenis data yang terlibat dalam sistem ini, yaitu :

a. Data Dasar

b. Data Spesifik

\subsection{Tahapan Umum Pengembangan GIS}

proses tahapan pembangunan sistem informasi geografi dapat dijelaskan sebagai berikut: Akuisisi (Pengumpulan) data, baik data dari hasil delineasi citra satelit, data spasial (peta) yang ada maupun data atribut. Data satelit yang dimaksud adalah hasil konversi akhir dari proses penginderaan jauh seperti diterangkan pada bagian yang lain dalam proposal teknis ini.

a. Data peta yang ada dapat diperoleh dari instansi-instansi penyedia peta seperti Bakosurtanal, BPN, PU, Geologi, Bappeda dan instansi swasta lain-lain baik dalam format digital maupun dalam hardcopy. Sedangkan data atribut dapat diperoleh dari berbagai instansi seperti BPS, Depdagri, BPN dan instansi swasta lain-lain.

b. Digitasi peta, yaitu mengubah peta analog menjadi peta dengan format digital, jika data yang ada adalah peta analog (peta kertas).

c. Editing dan Edge-matching, proses editing adalah proses perbaikan data peta hasil digitasi misalnya ada objek yang terdigit 2 kali. Sedangkan edgematching adalah proses penyatuan 
lembar peta yang bersebelahan, objek yang ada di peta harus kontinyu dengan peta yang di sebelahnya.

d. Transformasi, topologi dan geocode. Transformasi yaitu proses pemindahan koordinat dari satu sistem proyeksi ke sistem proyeksi yang lain. Topologi merupakan proses penyusunan struktur data spasial dengan data atribut. Sedangkan geocoding adalah proses pengidentifikasian data spasial agar terhubungkan dengan data spasialnya.

e. Analisa, proses analisa merupakan proses manipulasi basis data yang telah terbangun sehingga basis data tersebut dapat menghasilkan peta atau data tabular yang diinginkan.

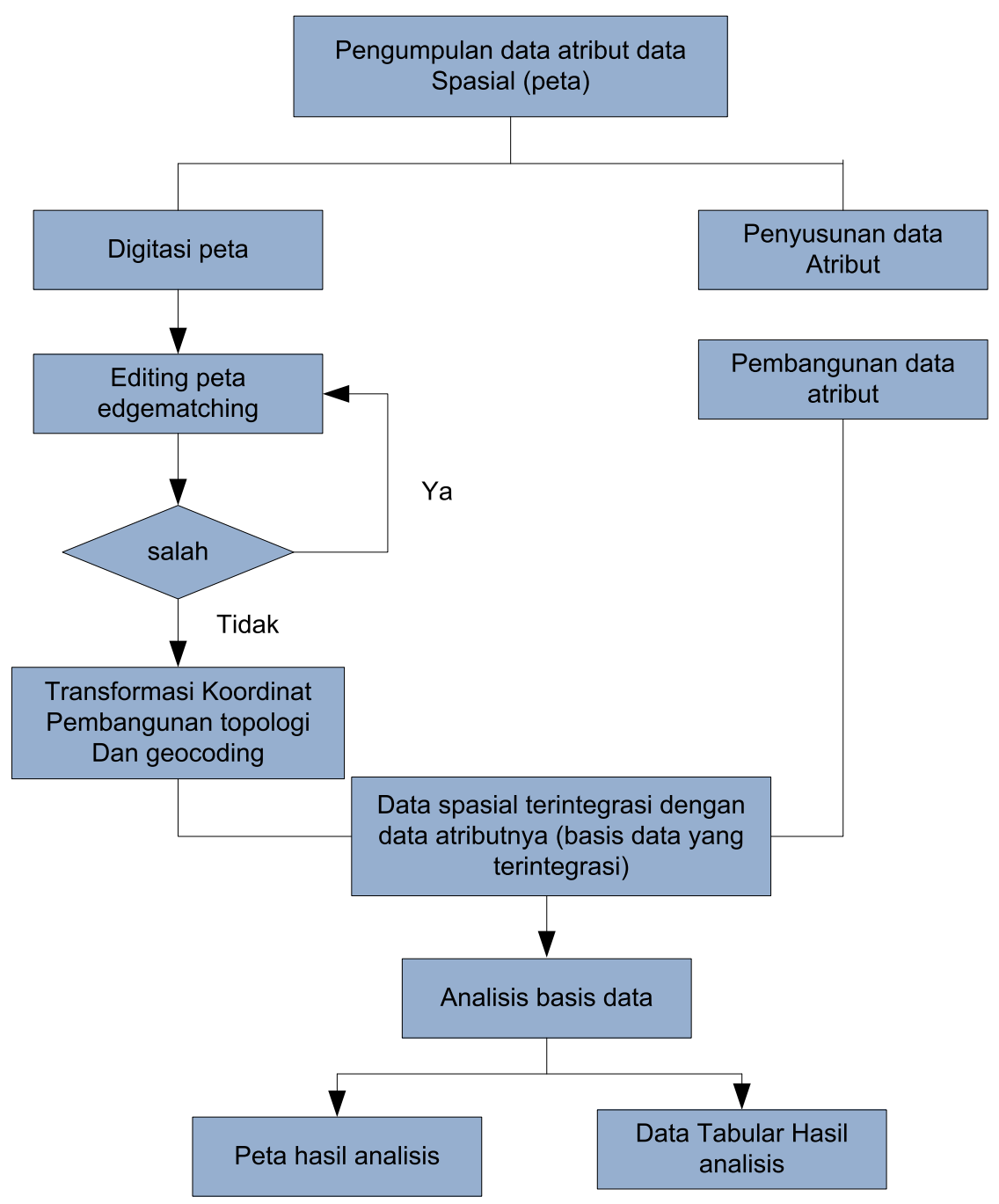

Gambar 4 Diagram alir Proses pembangunan GIS

\section{Metodologi Penelitian}

Tahapan-tahapan untuk menyelesaikan masalah terkait dengan Pembuatan Informasi Data Spasial Bangunan Yang Memiliki KRK-IMB menggunakan tahapan-tahapan analisa kebutuhan dan pengembangan sistem sebagai berikut: 


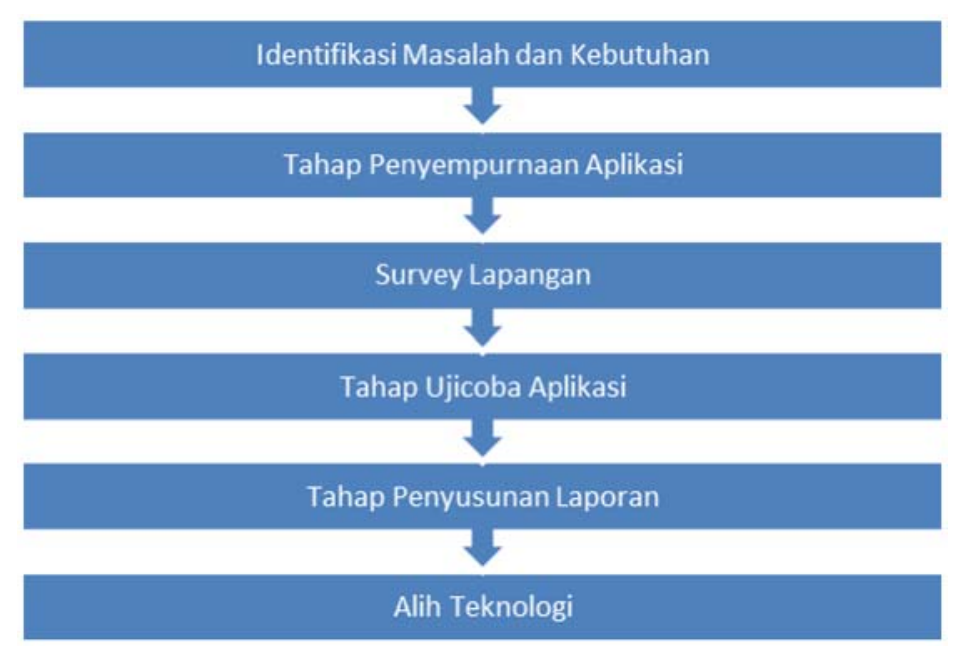

Gambar 5. Metodologi Pekerjaan

\subsection{Identifikasi Masalah dan Kebutuhan Analisa Sistem}

Seperti yang telah dikemukakan sebelumnya bahwa pembuatan Pembuatan Informasi Data Spasial Bangunan Yang Memiliki KRK-IMB Kota XYZ memiliki beberapa tujuan yaitu terdiri dari:

a. Meningkatkan mutu layanan publik melalui pemanfaatan teknologi IT dalam proses penyelenggaraan pemerintahan

b. Terbentuknya kepemerintahan yang bersih, transparan, dan mampu menjawab tuntutan perubahan secara efektif

c. Perbaikan organisasi, sistem manajemen, dan proses kerja kepemerintahan

Dinas Tata Ruang Tata Bangunan dan Perumahan (DTRTBP) Kota XYZ saat ini telah memiliki sistem informasi proses pengurusan KRK-IMB, namun aplikasi perlu di kembangkan, sehingga diperlukan penyempurnaan terhadap sistem informasi data spasial bangunan. Selain dari kegiatan penyempurnaan terhadap sistem informasi yang telah dimiliki oleh DTRTBP, terdapat kegiatan lainnya yaitu, penambahan basis data bangunan yang telah memiliki KRK-IMB tahun 2013.

Dengan kegiatan penyempurnaan sistem informasi dan penambahan basis data bangunan, maka sasaran dari DTRTBP yaitu tercapainya efisiensi dan efektifitas pelayanan perijinan Kota XYZ melalui ketersediaan pemutakhiran data bangunan yang memiliki KRK-IMB.

\subsection{Alur Proses Perijinan}

Adapun tahap proses perijinan KRK-IMB pada DTRTBP Kota XYZ adalah sebagai berikut :

a. Pemohon melakukan permohonan dengan melampirkan fotocopy KTP yang masih berlaku, fotocopy hak atas tanah yang dilegalisir, gambar bangunan rangkap 6, gambar 
kontruksi rangkap 6 (bangunan bertingkat), dan perhitungan konstruksi (lantai 3 dan seterusnya), persyaratan lain sesuai kebutuhan.

b. Permohonan diterima oleh Bidang Tata Bangunan, kemudian dilakukan pemeriksaan administrasi pendistribusian berkas permohonan (1 hari), Kemudian dilakukan juga pemeriksaan gambar arsitektur dan konstruksi bangunan, pengukuran ke lokasi, membuat gambar situasi bangunan, dan menghitung restribusi (RAMMING)

c. Jika permohonan lahan kurang dari $1000 \mathrm{~m}^{2}$, permohonan akan dilanjutkan pada Bidang Tata Ruang

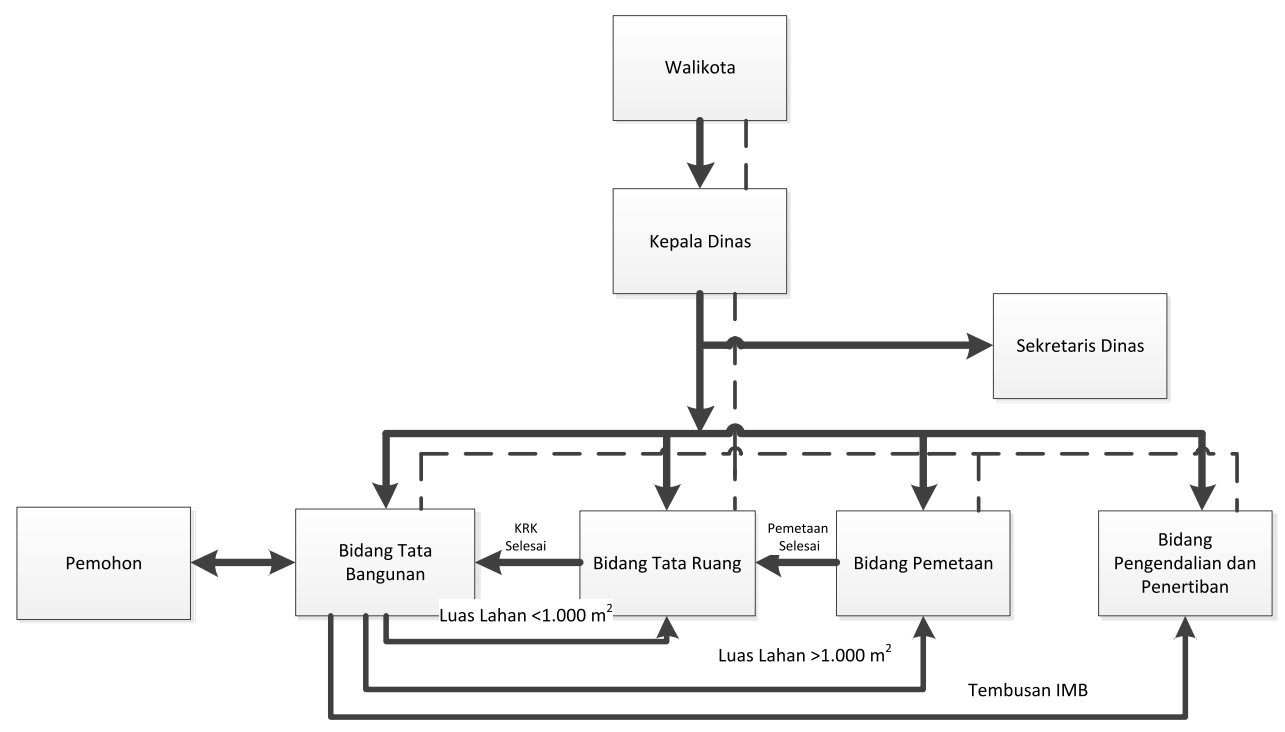

Gambar 6. Alur Proses Perijinan KRK-IMB

\subsection{Survei Lapangan}

Survei lapangan dilakukan untuk mendapatkan koordinat dan gambar bangunan sesuai SKIMB. Untuk menyelesaikan seluruh kegiatan pekerjaan ini sesuai dengan metodelogi pekerjaan yang telah disusun dibutuhkan data-data yang dikumpulkan dengan berbagai metoda pegumpulan data. Namun untuk lebih mengefektifkan waktu perlu diidentifikasi terlebih dahulu data eksisting serta kebutuhan data dan disesuaikan dengan analisis yang akan dilakukan. Dari listing kebutuhan data dapat diidentifikasi metoda pengumpulan data yang mungkin dapat dilakukan untuk memenuhi kebutuhan data.

Berikut pada Tabel 3.1 disampaikan sejumlah kebutuhan data berikut kegunaan data tersebut.

Tabel 1. Kebutuhan Data dan Kegunaan Data

\begin{tabular}{|l|l|c|c|c|}
\hline No. & Jenis Data & Item Detail Data & Kegunaan Data & Sumber Data \\
\hline 1. & Peraturan, & - Peraturan yang & - Menyusun & -Departemen \\
& $\begin{array}{l}\text { pustaka/literatur } \\
\text { dan studi terkait, } \\
\text { Sistem Eksisting }\end{array}$ & $\begin{array}{c}\text { terkait dengan data } \\
\text { spasial KRK-IMB }\end{array}$ & $\begin{array}{c}\text { konsep sistem } \\
\text { informasi data }\end{array}$ & $\begin{array}{c}\text { terkait } \\
\text {-Literatur }\end{array}$ \\
\hline
\end{tabular}




\begin{tabular}{|c|c|c|c|c|}
\hline No. & Jenis Data & Item Detail Data & Kegunaan Data & Sumber Data \\
\hline & & $\begin{array}{l}\text { - Teori terkait } \\
\text { pengembangan } \\
\text { sistem informasi } \\
\text { data spasial KRK- } \\
\text { IMB } \\
\text { - Hasil studi-studi } \\
\text { terkait Manfaat } \\
\text { Sistem }\end{array}$ & $\begin{array}{l}\text { spasial KRK- } \\
\text { IMB } \\
- \text { Menyusun } \\
\text { rancangan } \\
\text { desain aplikasi } \\
\text { data spasial } \\
\text { KRK-IMB } \\
- \text { Mendapatkan } \\
\text { Software yang } \\
\text { user frienly bagi } \\
\text { DTRTBP } \\
\end{array}$ & \\
\hline 2. & $\begin{array}{l}-\mathrm{KRK} \\
-\mathrm{IMB}\end{array}$ & $\begin{array}{l}\text { - Data tipologi KRK } \\
\text { - Data IMB }\end{array}$ & 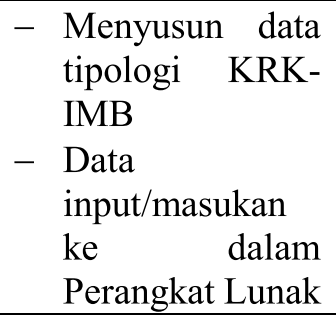 & $\begin{array}{l}\text {-Survey } \\
\text { primer } \\
\text {-Survey } \\
\text { sekunder }\end{array}$ \\
\hline 3. & Data wawancara & $\begin{array}{l}\text { - Masukan KRK- } \\
\text { IMB } \\
\text { - Masukan } \\
\text { komponen } \\
\text { masukan, } \\
\text { pengolahan dan } \\
\text { penyajian data } \\
\text { - Masukan terhadap } \\
\text { model/bentuk } \\
\text { aplikasi } \\
\end{array}$ & $\begin{array}{l}\text { - Identifikasi } \\
\text { kebutuhan } \\
\text { aplikasi } \\
\text { - Menyusun } \\
\text { konsep rancang } \\
\text { model yang akan } \\
\text { digunakan }\end{array}$ & $\begin{array}{l}\text {-Survey } \\
\text { wawancara }\end{array}$ \\
\hline
\end{tabular}

Metoda Pengumpulan Data

Untuk mempermudah proses mendapatkan data yang dibutuhkan di atas, maka perlu kiranya disusun suatu metoda pengumpulan data yang komprehensif dan terstruktur sehingga dapat memanfaatkan waktu yang disediakan sesuai arahan dalam Kerangka Acuan Kerja. Untuk itu dalam studi ini digunakan sejumlah metoda survey sebagai berikut:

a. Survey data sekunder (instansional) dilakukan untuk mengumpulkan literatur serta data sekunder di instansi

b. Survey Primer di lapangan yang dilakukan dengan peninjauan langsung di lapangan untuk mendata proses /alur dokumen, alur data / prosedur dan persyaratan perijinan KRKIMB Kota XYZ yang menjadi kewenangannya. Agar pelaksanaan survey primer di lapangan dapat dilakukan secara efektif dan efisien, perlu diperhatikan bentuk formulir survey yang harus disesuaikan dengan analisis Sistem di kembangkan yang akan disajikan dalam perangkat lunak ini.

c. Survey wawancara/kuisioner dengan mewawancarai stakeholder untuk memperoleh infomasi terkait dengan masukan data KRK-IMB, masukan komponen masukan, pengolahan dan penyajian data dan masukan terhadap model/bentuk perangkat lunak. 


\section{Perancangan Sistem 4.1 Tahap Persiapan}

Pada tahap ini kegiatan yang dilakukan antara lain:

a. Koordinasi tim dan pembagian tugas.

b. Menyusun jadwal rencana pelaksanaan pekerjaan, persiapan pelaksanaan pekerjaan dimulai dengan konsolidasi tim, pengumpulan data awal Pembuatan Informasi Data Spasial Bangunan Yang Memiliki KRK-IMB , mengumpulkan data/informasi pendukung kegiatan terkait.

\subsection{Tahap Perencanaan}

Pada tahap ini awal dalam pelaksanaan pekerjaan dalam mendapatkan data (collection data) yang tepat, terutama data spasial bangunan yang memiliki KRK-IMB. Teknik yang digunakan dalam data collection memungkinkan konsultan untuk secara sistematis mengumpulkan informasi-informasi yang dibutuhkan, yang sesuai dengan tujuan pekerjaan. Data yang digunakan dalam pekerjaan ini adalah bersumber dari data yang sudah ada (Data Sekunder).

Pengumpulan data sekunder merupakan pengumpulan data yang mudah dan cepat, karena data yang dibutuhkan sudah tersedia seperti database existing KRK-IMB di Dinas Tata Ruang Tata Bangunan dan Perumahan (DTRTBP) Kota XYZ.

\subsection{Tahap Pelaksanaan}

Tahapan pelaksanaan kebutuhan sistem didasarkan hasil survey dari kondisi eksisting yang ada dan literatur serta teori yang menjadi landasan Pembuatan Informasi Data Spasial Bangunan Yang Memiliki KRK-IMB kota XYZ. Kegiatan pada tahap pelaksanaan kebutuhan sistem ini terdiri dari beberapa bagian, Rancangan konseptual dan rancangan basis data.

\subsubsection{Rancangan Konseptual}

Pada tahap ini berdasarkan hasil studi dan analisis yang telah dilakukan, para anggota tim ahli melakukan:

1. Perancangan Sistem dan Prosedur : Berlandaskan hasil survey dan analisis sistem dan prosedur, dilakukan pembuatan rancangan dan menyusun konsep sistem dan prosedur.

2. Perancangan Konsep: Pada tahap ini akan disusun suatu konsep sistem yang terintegrasi dan terdiri dari klasifikasi data, model-model aplikasi.

Rancangan Basis Data dan Sistem

Adapun rancangan database adalah sebagai berikut :

- Krk_id

- Krk_blnarsip

- No imb

- Krk_noreg 
- No_krk

- Status

- Krk_statusijin

- Stat

- Stat1

- Krk file

- Krk_tahun

- Krk_bulan

- Krk_lokasibangunan

- Krk kecamatan

- Krk_kelurahan

- Krk_tglreg

- Krk_nama_pemohon

- Krk_alamatpemohon

- Krk_tglpengesahan

- Krk_nosurattanah

- Krk_skpdproses

- Krk_jenispermohonan

- Krk_kode

- Krk_kegiatanbangunan

- Krk_luastanah

- Krk_luaslahanefektif

- Krk_gsb

- Krk_damija

- Krk_dms

- Krk_kdb

- Krk_kb

- Krk_klb

- Krk_kdh

- Krk_terkenarencjalan

- Krk_restribusi

- Krk_pimpinan

\subsection{Aliran Kerja Sistem Eksisting}

\subsubsection{Penyajian Informasi Rencana DTRTBP Kota XYZ}

Sesuai dengan informasi yang diperoleh dari hasil wawancara bahwa penyajian informasi rencana tata ruang Kota XYZ, seperti informasi regulasi, persyaratan-persyaratan yang harus dipenuhi dalam permohonan perijinan, informasi data $\mathrm{RT} / \mathrm{RW}$ dan informasi lainnya yang terkait dengan permohonan perijinan KRK dan IMB, masih menggunakan media konvensional yaitu dengan menggunakan media papan pengumuman dan pemberian informasi dari staf DTRTBP. Dengan media konvesional tersebut maka pelayanan terhadap masyarakat tidak bisa optimal. 


\subsubsection{Pelayanan Perijinan}

Untuk dapat lebih memudahkan pemahaman terhadap cara pandang sistem yang berjalan saat ini, berbagai hasil wawancara, survey sistem dan SOP yang telah dipelajari dibuatkan model yang dapat merepresentasikan bagaimana gambaran sistem yang ada saat ini.

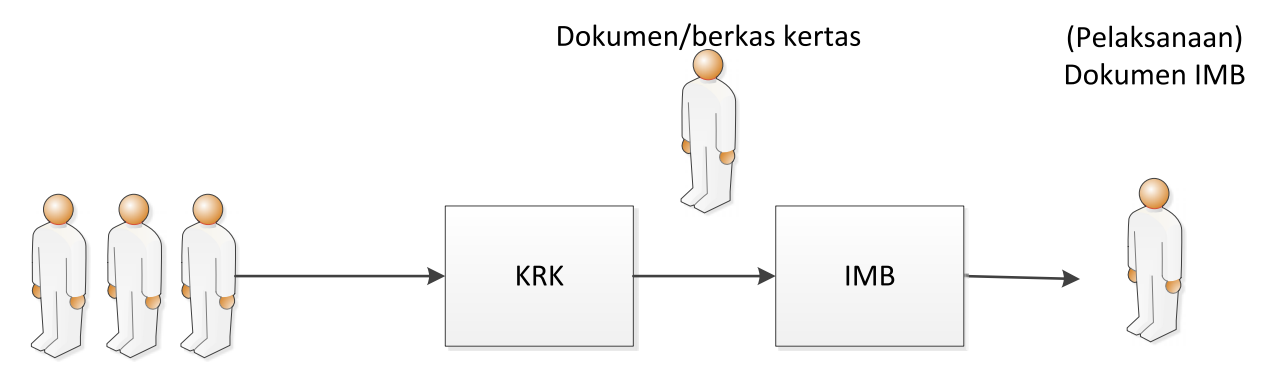

Gambar 7. Pelayanan Perijinan

Keterangan Gambar 7:

a. permohonan $\mathrm{KRK} \rightarrow$ penerbitan dokumen KRK

b. dokumen KRK $\rightarrow$ proses IMB $\rightarrow$ dokumen IMB

c. dokumen IMB $\rightarrow$ pelaksanaan pembangunan oleh pemohon

\subsection{Analisis Sistem Informasi Data Spasial Bangunan Yang Memiliki KRK-IMB}

Sistem Informasi Data Spasial Bangunan Yang Memiliki KRK-IMB Kota XYZ merupakan kumpulan dari beberapa fitur yang saling kerkaitan dalam mengelola data KRK dan IMB Kumpulan Fitur Sistem Informasi Data Spasial Bangunan Yang Memiliki KRK-IMB terdiri dari :

a. Fitur penyajian data dalam bentuk tabel yang berisikan data-data KRK, IMB, Pengawasan dan pengendalian berupa jumlah, lokasi, jenis kegiatan. Data tabel ini untuk melihat data KRK, IMB dan Pengawasan dan pengendalian dalam bentuk table dan visual.

b. Fitur penyajian data dalam bentuk peta SIG yang berisikan Sistem Informasi Geografis untuk melihat tampilan peta-peta yang berisikan :

c. Peta Pola Ruang

- Peta Pola Ruang

- Perencanaan

- Cari Koord

a. Pengkaplingan

- Pengkaplingan $>=$ Tahun 2013

- Pengkaplingan $>=$ Tahun 2000-2012

- Pengkaplingan $>=$ Tahun 1991-1999

b. Data Perizinan :

- KRK-IMB (Proses)

- KRK-IMB (Selesai)

- KRK-IMB (Ditolak) 
- Tabel KRK

c. Tabel Pengkaplingan

d. Tabel Perizinan KRK

- Edit/Entry Data KRK

- Cari Lokasi KRK

- Bantuan Modul

- Update Lokasi Tabel KRK

- Ident Lokasi Pendataan KRK

e. Fasilitas Jasa (Kawasan)

f. Pelaporan

g. Close

Fitur penyajian menu yang berisikan Proses Entry dan Editing Data KRK- IMB

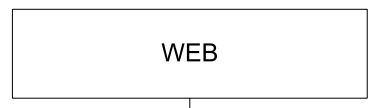

Gambar 8. SiteMap Aplikasi Sistem Hnformasi Data Spasial Bangunan Yang Memiliki KRK-IMB

\begin{tabular}{|c|}
\hline \multicolumn{2}{|c|}{ Peta } \\
\hline \multicolumn{2}{|c|}{ Pengkaplingan } \\
\hline \multicolumn{2}{|c|}{ Data Perizinan } \\
\hline \multicolumn{2}{|c|}{ KRK-IMB (Proses) } \\
\hline \multicolumn{2}{|c|}{ KRK-IMB (Selesai) } \\
\hline \multicolumn{2}{|c|}{ KRK-IMB (Ditolak) } \\
\hline \multicolumn{2}{|c|}{ Tabel Perizinan KRK } \\
\hline \multicolumn{2}{|c|}{ Fasilitas Jasa (Kawasan) } \\
\hline \multicolumn{2}{|c|}{ Pelaporan } \\
\hline
\end{tabular}

\subsection{Perancangan Sistem}

Mengacu pada hasil analisis pada bab terdahulu, maka pada bab ini akan dibahas tentang perancangan sistem yang akan dikembangkan. Perancangan sistem ini akan menghasilkan model-model yang akan digunakan untuk pembangunan perangkat lunak pada bab berikutnya.

\subsubsection{UML Mode}

Untuk memberikan gambaran tentang sistem yang dibangun, berikut akan dipaparkan berbagai macam bentuk model rancangan dari sistem yang akan dibangun. Model rancangan yang dibuat akan menggunakan UML model, karena sesuai dengan pemanfaatan Object Oriented Programming yang digunakan nantinya saat memasuki tahapan implementasi.

\subsubsection{Use Case}


Guna memberikan gambaran kepada client tentang bagaimana sistem akan berjalan, maka akan dibuat sebuah use case model seperti yang dapat dilihat pada gambar 5.4. Use case model ini, pada dasarnya merupakan sebuah peningkatan atau perbaikan yang dilakukan pada sistem yang saat ini berjalan. Dengan

model ini, client diberikan gambaran secara umum tentang bagaimana sistem nantinya berjalan.

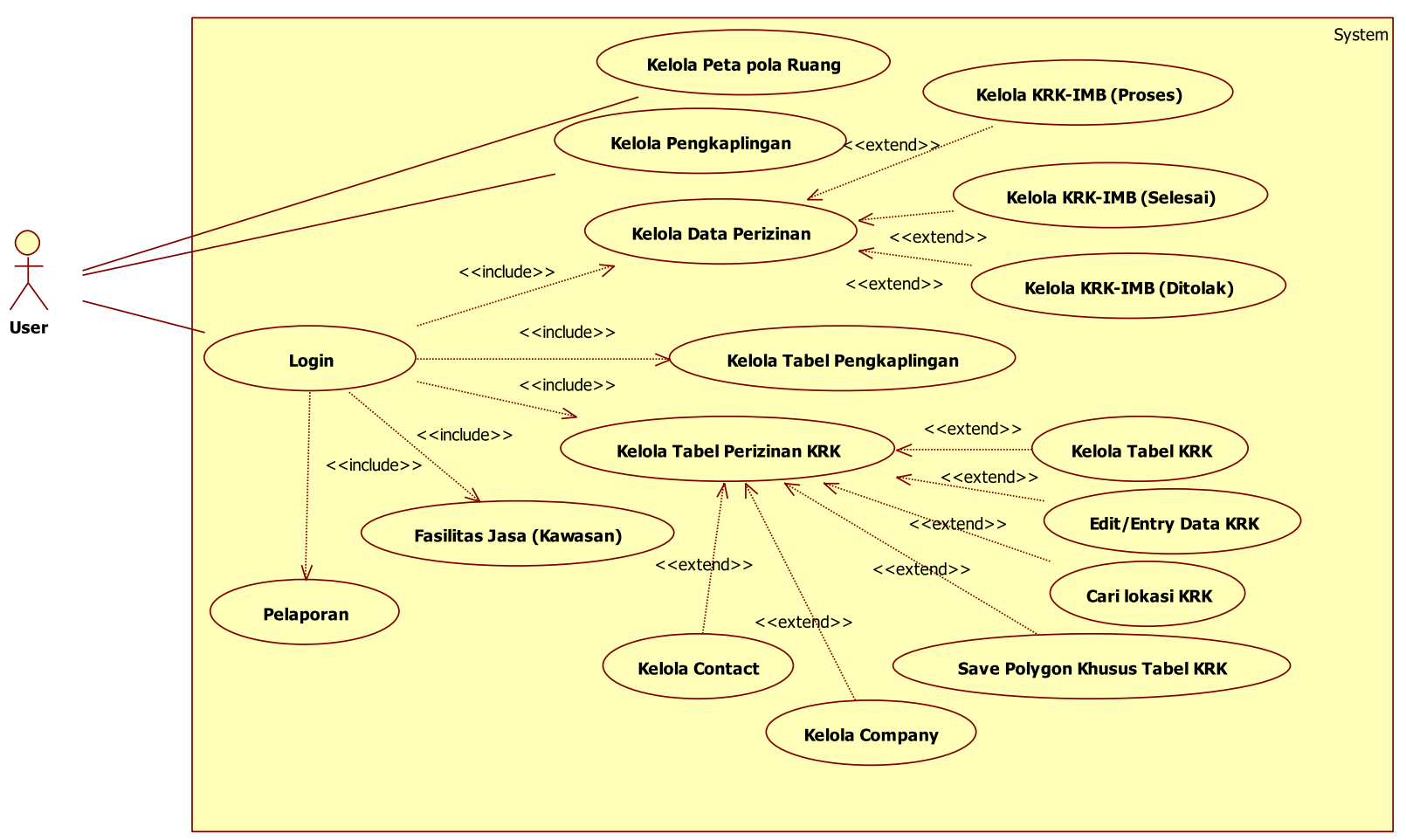

Gambar 9. Use Case Diagram Web Sistem Informasi Data Spasial Bangunan Yang Memiliki KRKIMB

Pada model use case tersebut, terdapat 1 orang aktor yakni User. Aktor User memiliki kewenangan untuk dapat mengelola data IMB-KRK, mengingat data yang dikelola pada sistem ini bersifat rahasia, menyangkut informasi tentang kepemilikan tanah atau bangunan, maka perlu dibatasi orang-orang yang diberikan hak akses ke dalam sistem.

\subsubsection{Sequence Diagram}


Pada bagian ini akan dibahas tentang sequence diagram. Diagram ini memberikan gambaran sistem secara sistematik pada saat melakukan berbagai proses yang mengacu pada diagram user.

Fasilitas yang dapat digunakan oleh User yang telah diotorisasi oleh sistem adalah melihat informasi terkait dengan Pembuatan Informasi Data Spasial Bangunan Yang Memiliki KRK-IMB melalui aplikasi berbasis web seperti pada gambar 10 .

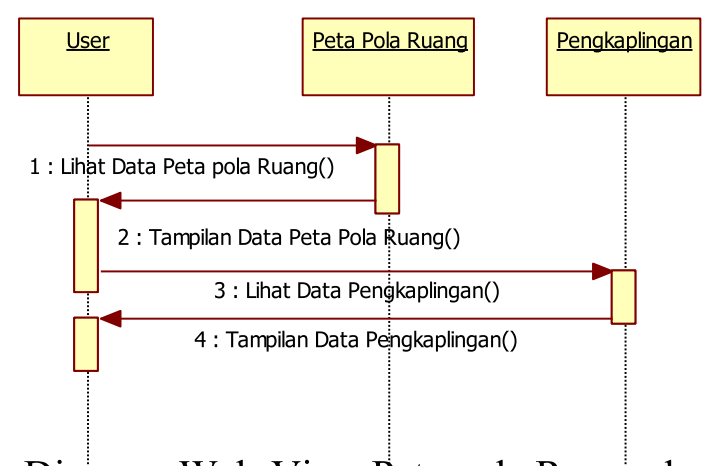

Gambar 10. Sequence Diagram Web-View Peta pola Ruang dan Pengkaplingan

Sequence Diagram Aktor User ( Login KRK)

Pemanfaatan data yang telah disimpan dalam bentuk database pada sistem aplikasi berbasis web yang bertujuan untuk mengawasi dan pengendalian tata ruang Kota XYZ. Rancangan sistem pengendalian dan pengawasan tata ruang Kota XYZ oleh User (Login KRK) seperti yang terdapat pada gambar 11 Keberadaan fasilitas tersebut hanya dapat diakses oleh aktor Staff DTRTBP yang ditunjuk. Kewenangan aktor ini dapat mengelola data baik berupa input, edit dan hapus data.

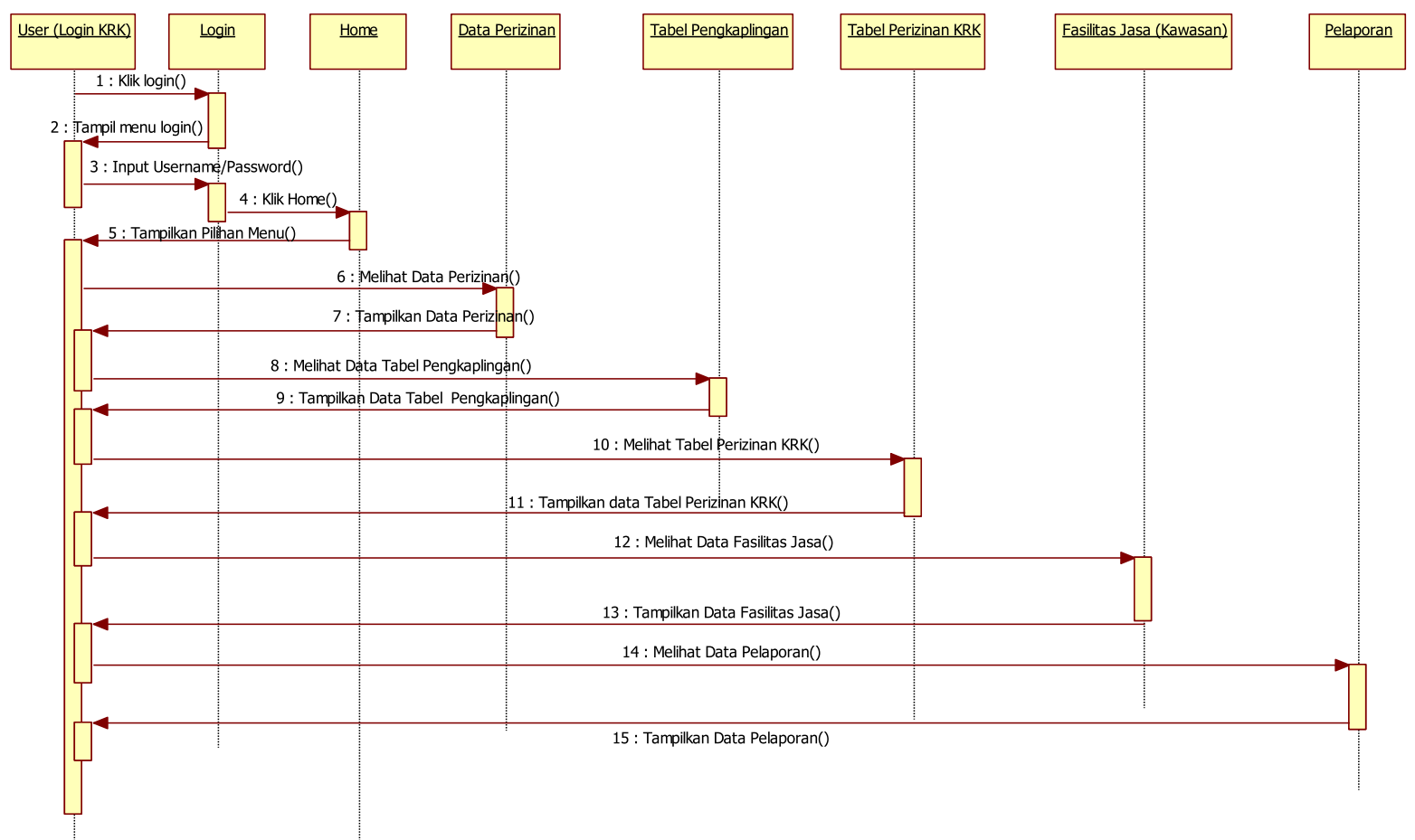

Gambar 10. Sequence Diagram Aktor User (Login KRK) Kelola Data KRK-IMB 


\subsubsection{Interface Design Model}

Pada bagian ini akan dibahas antarmuka yang akan dijadikan acuan untuk pengembangan aplikasi nanti pada bab selanjutnya. Design model yang digunakan belum menampilkan tampilan sebenarnya dari sistem, namun lebih mengutamakan kepada menampilkan berbagai fungsi-fungsi utama yang ada pada sistem. Model-model ini akan mempermudah tahapan pengembangan aplikasi nantinya, karena pada dasarnya fungsi-fungsi utama pada aplikasi sudah dapat dilihat pada model rancangan user interface (UI).

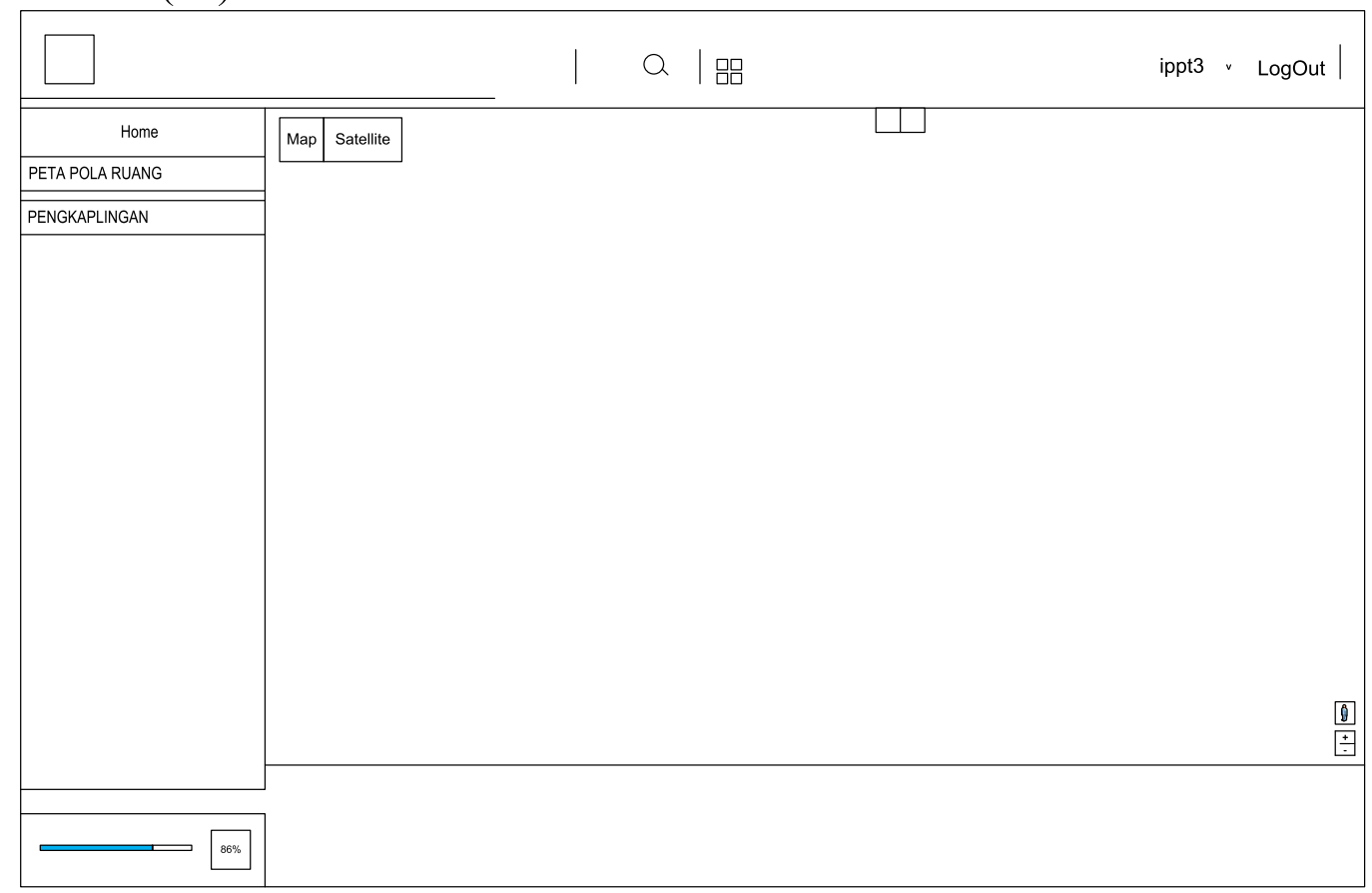

Gambar 11. Interface Model GIS-View Aplikasi Sistem Informasi Data Spasial Bangunan Yang Memiliki KRK-IMB 


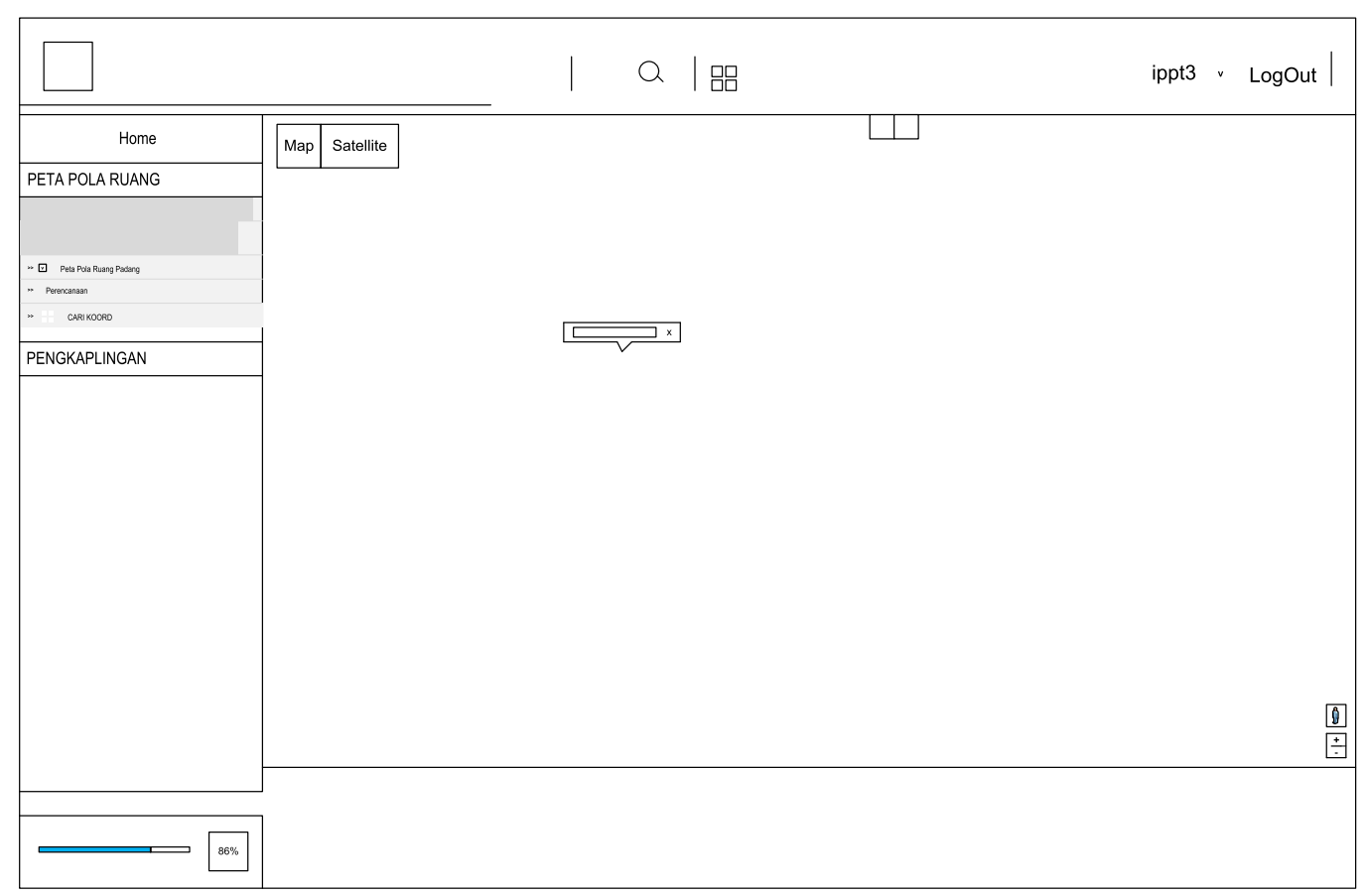

Gambar 12. Interface Model GIS-View Peta Pola Ruang

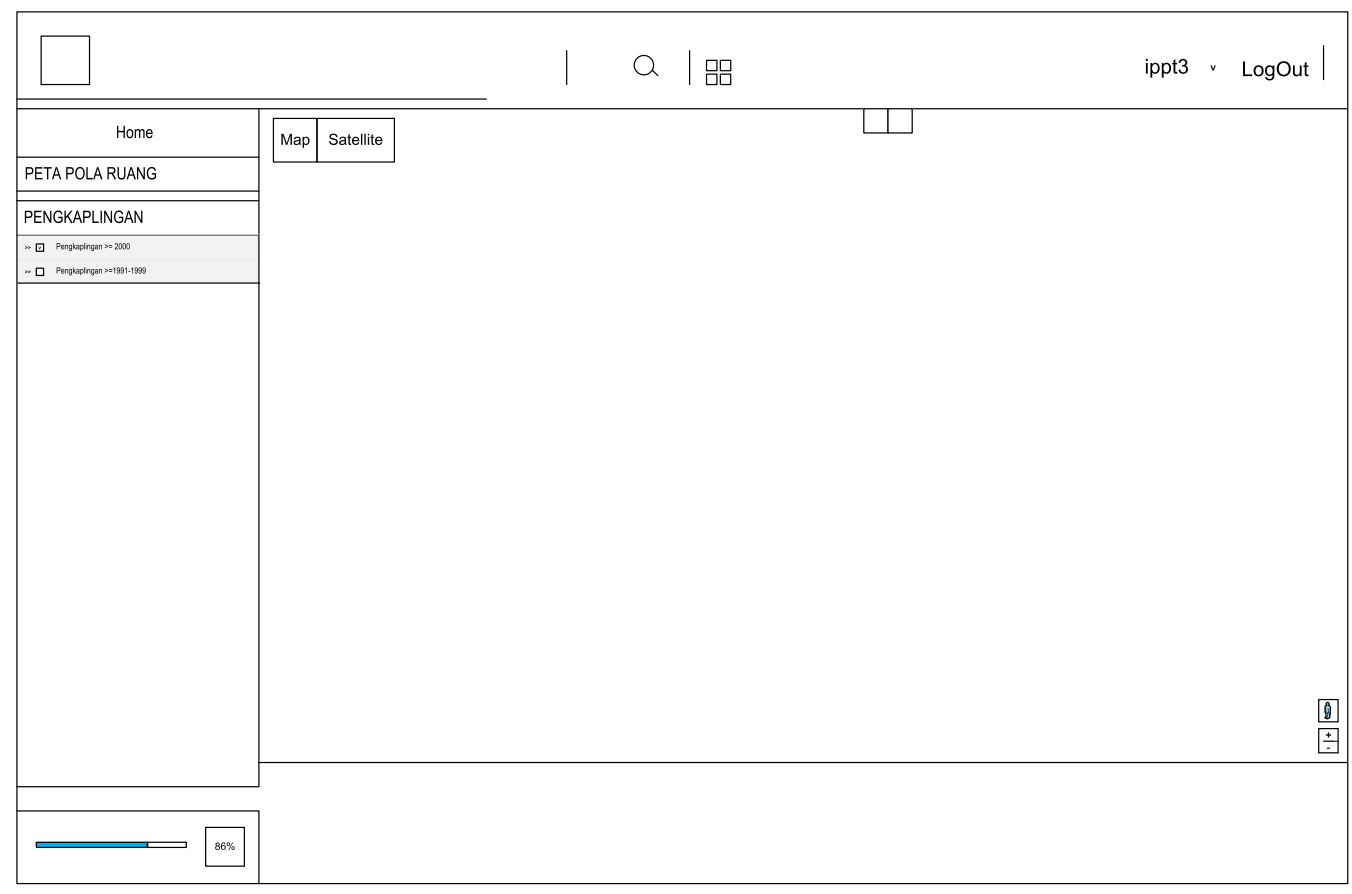

Gambar 13. Interface Model GIS-View Pengelompokan Pengkaplingan 


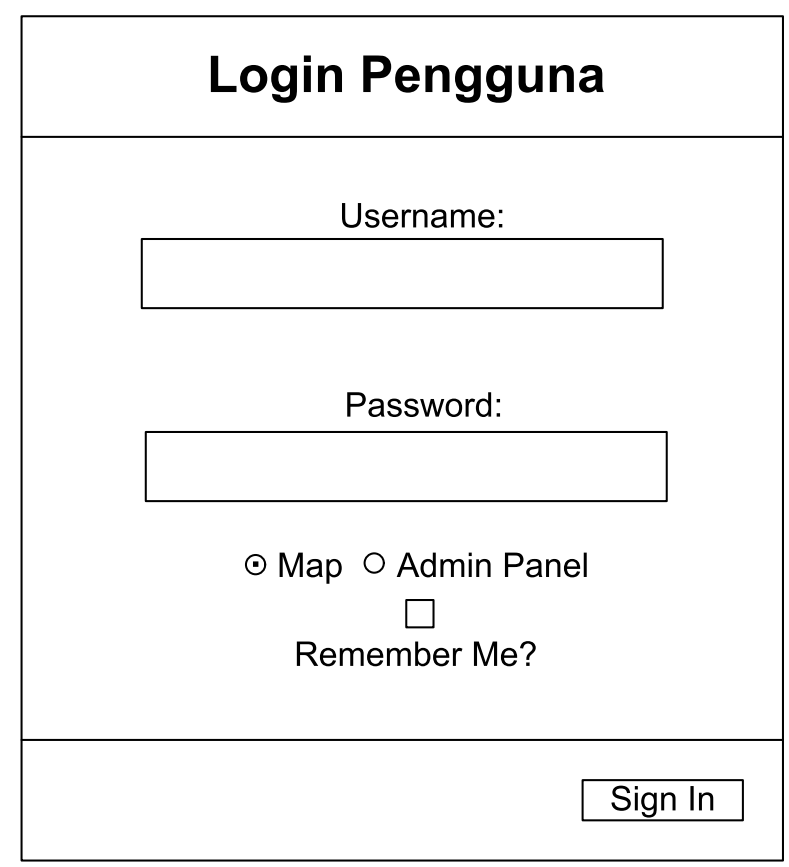

Gambar 14. Interface Model GIS-View Login Pengguna

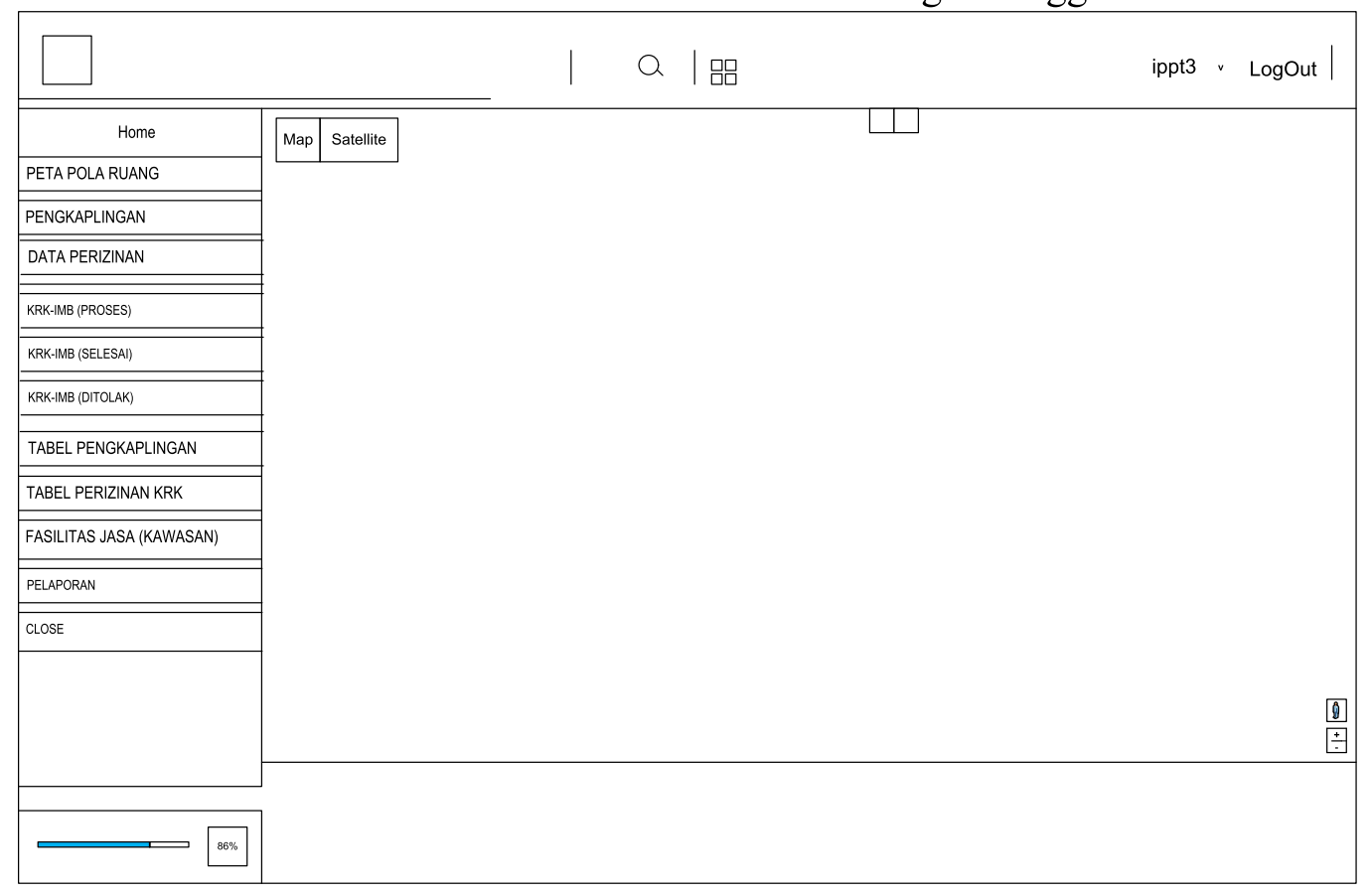

Gambar 15. Interface Model GIS-View Halaman Utama Login User KRK 


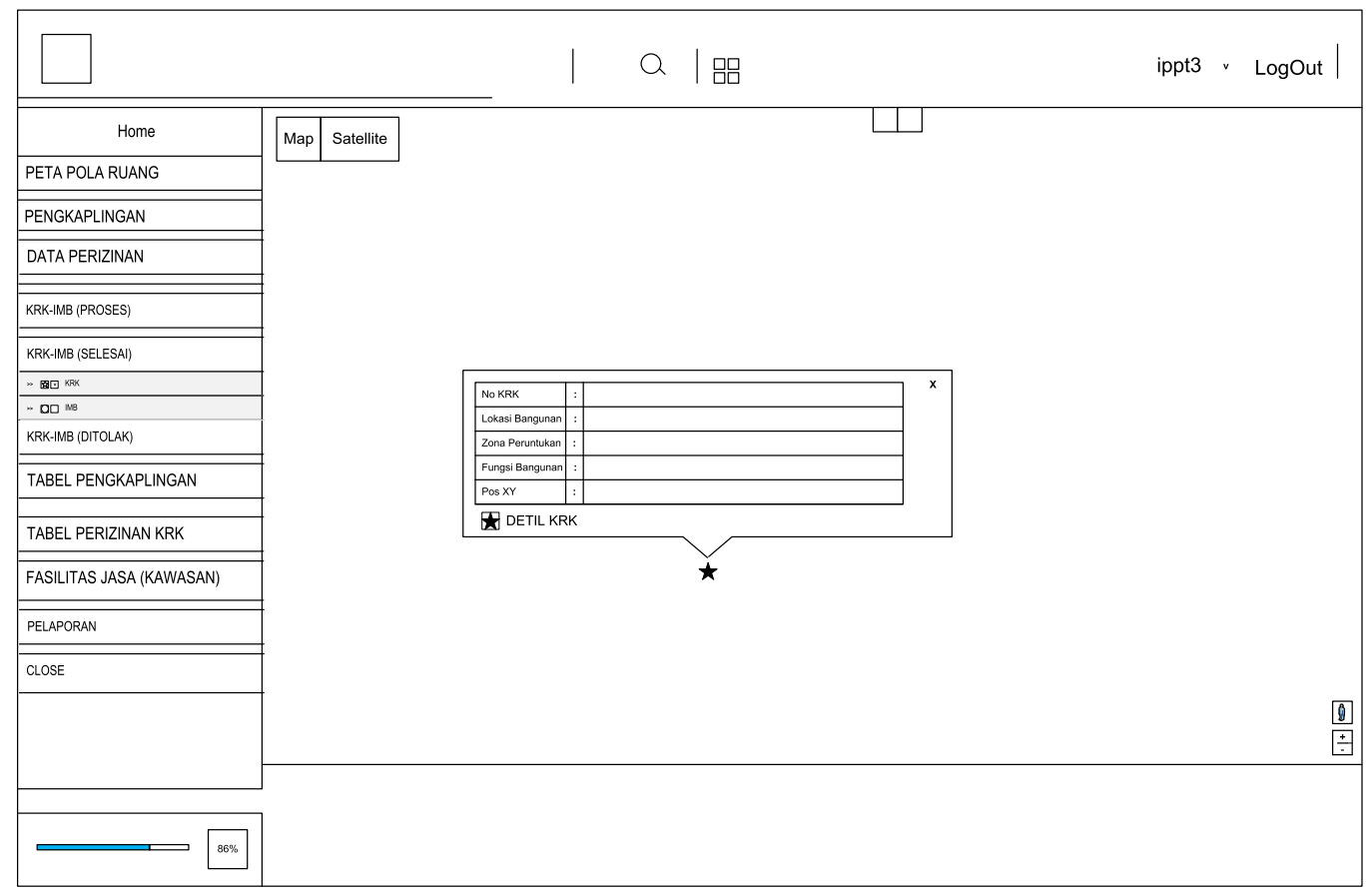

Gambar 16. Interface Model GIS-View Halaman KRK-IMB (Selesai) - KRK

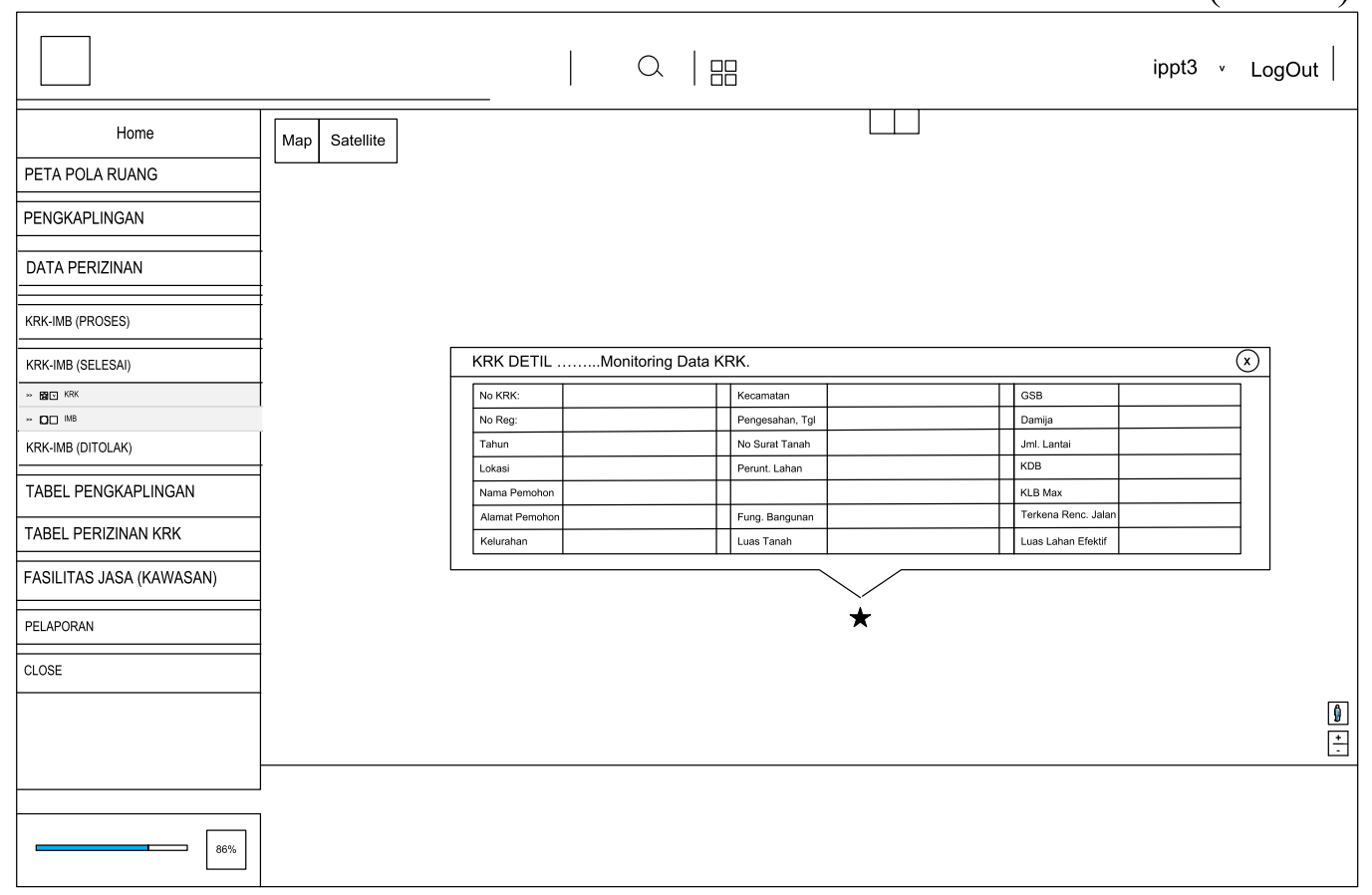

Gambar 17. Interface Model GIS-View Halaman KRK-IMB (Selesai) KRK - Detil KRK 


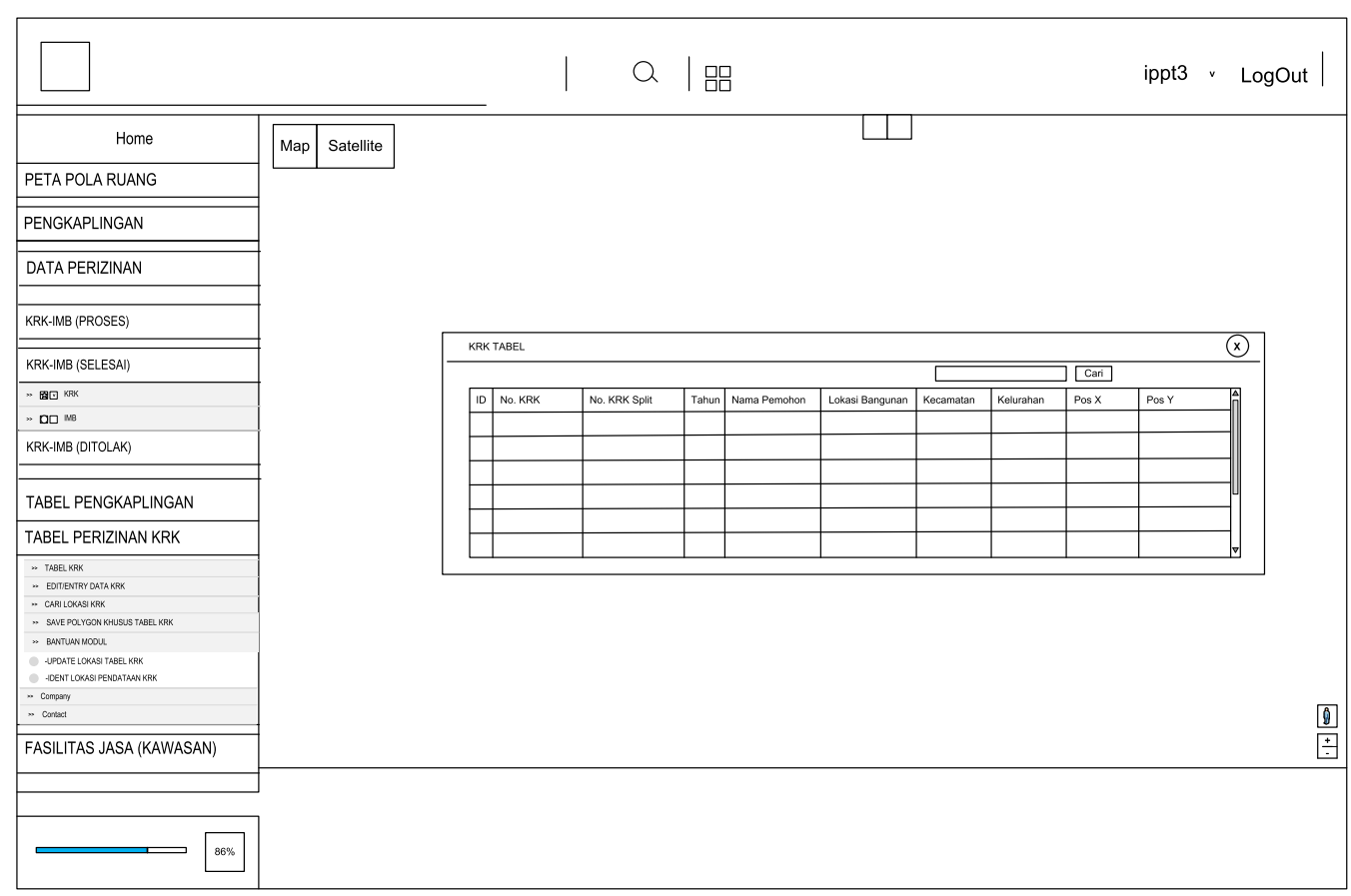

Gambar 18. Interface Model GIS-View Halaman Tabel Database KRK

\section{Kesimpulan}

Adanya penyempurnaan aplikasi informasi data spasial bangunan yang memiliki KRKIMB. Penambahan basis data spasial bangunan yang telah memiliki KRKIMB. Dengan adanya aplikasi informasi ini adalah tercapainya efisiensi dan efektifitas pelayanan KRK-IMB Kota XYZ melalui ketersediaan pemutakhiran data bangunan yang memiliki KRK-IMB.

\section{Daftar Pustaka :}

[1] Undang-Undang Nomor 26 Tahun 2007 tentang Penataan Ruang

[2] Peraturan Pemerintah Nomor 15 Tahun 2010 tentang Penyelenggaraan Penataan Ruang

[3] Peraturan Menteri Dalam Negeri Nomor 8 Tahun 1998 tentang Perencanaan Penataan Ruang

[4] M.Shalahuddin, Rosa A.S 2013. Rekayasa Perangkat Lunak.Informatika, Bandung

[5] Budianto, Eko. 2010. Sistem Informasi Geografis dengan Arc View GIS. Yogyakarta: Andi Offset. 